\title{
But There Is Magic, Too: Confronting Adolescents' Realities in Francesca Lia Block's Fairy-Tale Rewritings
}

\author{
Marie Emilie Walz
}

check for

updates

Citation: Walz, Marie Emilie. 2021. But There Is Magic, Too: Confronting Adolescents' Realities in Francesca Lia Block's Fairy-Tale Rewritings. Humanities 10: 93. https://doi.org/ 10.3390/h10030093

Received: 7 June 2021

Accepted: 26 July 2021

Published: 29 July 2021

Publisher's Note: MDPI stays neutral with regard to jurisdictional claims in published maps and institutional affiliations.

Copyright: (C) 2021 by the author. Licensee MDPI, Basel, Switzerland. This article is an open access article distributed under the terms and conditions of the Creative Commons Attribution (CC BY) license (https:/ / creativecommons.org/licenses/by/ $4.0 /)$.
English Department, University of Lausanne, 1015 Lausanne, Switzerland; MarieEmilie.Walz@unil.ch

\begin{abstract}
Many rewritings of fairy tales use this genre to address the darkest, most violent, most unjust, and most painful aspects of human experiences, as well as to provide hope that it is possible to overcome or at least come to terms with such experiences. Francesca Lia Block's The Rose and the Beast: Fairy Tales Retold (pub. 2000) is an example of such a use of fairy-tale material. Block's stories transform traditional fairy tales to narrate the painful realities adolescents can be faced with in modern-day American society. In doing so, Block's stories draw attention to the violence, both literal and ideological, inherent in well-known versions of fairy tales, as well as to the difficulty of confronting painful realities. Yet, as they depict young heroines (not) facing all kinds of ordeals, the stories also use the figure of the helper to restore hope to the protagonists and lead them to a new, often re-enchanted, life. Employing fairy-tale elements to both address suffering and provide hope, The Rose and the Beast thus offers complex and liminal narratives, or 'anti-tales', which deeply resonate with their intended adolescent audience's in-between stage of life.
\end{abstract}

Keywords: fairy tales; fairy-tale rewritings; anti-tales; violence; trauma; healing; young adult fiction; Francesca Lia Block; The Rose and the Beast

\section{Introduction}

'Fairy tales', Marina Warner states in Once Upon a Time: A Short History of Fairy Tale, 'evoke every kind of violence, injustice, and mischance, but in order to declare it need not continue' (Warner 2014, p. xxiii). Warner's argument applies to so-called classic fairy tales as well as to rewritings of these fairy tales in different social, historical, and political contexts. Indeed, many retellings use the fairy-tale genre to address the darkest, most violent, most unjust, and most painful aspects of human experiences, and to provide hope that it is possible to overcome or at least come to terms with such experiences. Francesca Lia Block's collection of short stories The Rose and the Beast: Fairy Tales Retold (Block 2000) is an example of how recent fairy-tale rewritings 'evoke every kind of violence, injustice, and mischance' and 'declare it need not continue'. The stories in The Rose and the Beast transform fairy tales to narrate the painful realities adolescents can be faced with in modernday American society, such as drug addiction, sexual abuse, domestic violence, and even murder. In doing so, Block's stories draw attention to the violence inherent in the fairy-tale genre, which is both literal and ideological, and highlight the difficulties for teenagers to face their violent and painful realities, as well as to find alternatives to the crippling scenarios offered by well-known fairy tales. At the same time as they depict young heroines (not) facing all kinds of ordeals, Block's stories also use the figure of the magic helper to save or at least aid the main protagonist to confront her problems and reach a better, often re-enchanted, life. Employing fairy-tale elements to both address suffering and provide hope, Block's The Rose and the Beast thus offers complex and liminal narratives, or 'antitales', which deeply resonate with their intended adolescent audience's in-between stage of life. 


\section{Violence and Trauma in Fairy Tales and Fairy-Tale Rewritings}

Whereas in popular imagination, fairy tales are more often than not associated with innocence and happiness, scholars have shown that they also display violent, painful, and disturbing scenes and scenarios. The tale of Bluebeard, who murders his seven wives one after the other and keeps their bodies in his bloody chamber, is one remarkable example of a violent fairy tale (Warner 1995, pp. 241-71). Violence is also very much present in the punishments dealt to antagonists at the end of many fairy tales. In the Grimms' tales for example, Snow White's stepmother is forced to dance in red-hot iron shoes until she dies and Ashputtle's stepsisters have their eyes pecked out by doves. Elizabeth Wanning Harries calls such violence '[p]unitive or disciplinary' and argues that it is 'designed to caution children or to give the world a moral spin' (Harries 2005, p. 55). Harries also identifies in some fairy tales 'a kind of insidious, coercive violence often designed to force young girls into submission' (p. 55) and gives as examples tales of fathers attempting to have incestuous relationships with their daughters, but one can also think of mothers who inflict physical pain on their daughters so they can fulfil the roles they have devised for them (as in the Grimms' version of 'Ashputtle' or 'Cinderella', in which the stepmother cuts off parts of her daughters' feet to make them fit into the glass slipper and become princesses). Finally, many fairy tales feature scenes which have gruesome or disturbing implications. As Angela Carter points out in her short story 'Ashputtle or The Mother's Ghost' (pub. 1993) for instance, 'nothing in any of the many texts of this tale suggests the prince washed the shoe out between the fittings', so Ashputtle has to put her foot in the shoe 'still slick and warm' (Carter 1994, p. 116) with her stepsisters' blood. No less disturbing is the prince's request to the dwarfs in the Grimms' tale to have Snow White's glass coffin so he can always admire her; a request which has troubling necrophiliac undertones ${ }^{1}$. Far from being about innocence and happiness only, fairy tales thus feature explicit and implicit violence and pain, as well as gruesome and disturbing scenes.

In turn, many retellings and adaptations of fairy tales draw on their inherent violence and troubling elements for various purposes. Many fairy-tale rewritings bring out the gruesome, disturbing, and violent contents of fairy tales to highlight not only their latent darkest aspects but also the ideological violence they convey. Carter's rewriting of the 'Bluebeard' tale in her short story 'The Bloody Chamber' (pub. 1979) from the eponymous collection is one famous example. While the tale of Bluebeard has a long tradition of being read as cautioning against female curiosity, instead of focusing on Bluebeard's murders (Warner 1995, p. 243), Carter's rewriting 'self-consciously revisits a long history of physical, psychological, and symbolic violence against women' (de la Rochère 2013, p. 109). Carter's Bluebeard figure, the Marquis, does not only take after the fairy-tale character, but also after the Marquis de Sade and is hence not only a murderer but also a pornographer. Martine Hennard Dutheil de la Rochère convincingly shows how his fascination for decadent art, which he compulsively collects (Carter 2006, pp. 16-17), leads him to murder his wives and expose them in his bloody chamber in settings which reproduce his favorite art pieces (de la Rochère 2013, pp. 139-52). The association of pornographic art and murder in Carter's story not only refocuses the tale of 'Bluebeard' on the husband's killing of his wives and keeping their bodies in his bloody chamber, but also underlines the ideological subtext which reduces women to stereotypes of 'innocent virgins or dangerous whores, passive victims or wicked Eves' (pp. 136-37) and trivializes violence against them.

Likewise, Neil Gaiman's short story 'Snow, Glass, Apples' (pub. 1994), which retells the Grimms' version of 'Snow White' from the point of view of the stepmother, develops the necrophiliac undertones of the prince's request to highlight the ideological violence of reducing women to passive and inert objects of male desire. Drawing on the fact that Snow White, after being poisoned, seems dead and yet is not in the Grimms' tale, Gaiman's story transforms the innocent and passive Snow White into a vampire. The prince's encounter with this undead figure, imagined by the stepmother who narrates the story, then emphasizes how he is roused by the young girl's cold and motionless body (Gaiman 2005, pp. 382-83). As Jessica Tiffin argues, the introduction of the vampire 
from Gothic fiction into the fairy tale 'consequently serves to perform and articulate the gendered horror at the heart of the tale, externalizing into visible form the ideological violence already committed on Snow White's inactive female body' (Tiffin 2011, p. 225). The ideological violence of the tale is indeed the reduction of the female protagonist to a naïve and helpless young girl, as well as to being the passive and, in Cristina Bacchilega's words, 'frozen object of male desire' (Bacchilega 1997, p. 76). Rewritings like those by Carter and Gaiman thus draw on the disturbing and gruesome elements featured in fairy tales to address various forms of literal, physical and psychological, as well as ideological, violence perpetrated against women.

Conversely, recent rewritings of fairy tales have used the genre's inherent violence to narrate the most difficult and traumatizing human experiences. This is especially visible in novels which rewrite fairy tales in the context of the Holocaust, such as Jane Yolen's Briar Rose (Yolen 1992) or Louise Murphy's The True Story of Hansel and Gretel: A Novel of War and Survival (Murphy 2003), to cite only two examples. In these texts, the violence of the fairy tale merges with the horrors and traumas of the Holocaust, while the imaginary quality of the fairy tale also allows the authors to put a safe distance between the reader and the violent and painful events which are narrated. The fairy tale indeed becomes an allegory for the real traumatic event (Landwehr 2009, p. 154), which both makes it communicable and contains it within a well-known framework (Martínez-Alfaro 2020, p. 203). Furthermore, such texts do not only draw on the violent and disturbing aspects of fairy tales but also on their magic and enchanted atmosphere, which opens up possibilities of healing from the traumatic experience of the Holocaust. The use of the fairy-tale genre indeed 'gives [trauma] a recognizable shape and sense, a coherent moral vision, and promises a happy ending' (de la Rochère and Viret 2011, p. 402). In such rewritings, the violence of fairy tales is thus used as a means of representation for real traumatic events, while the magic also inherent in the genre fulfils a cathartic function.

In its representation of disturbing, painful, violent, and traumatic experiences, Block's The Rose and the Beast uses similar strategies as both the fairy-tale rewritings which denounce ideological violence and those which provide a safe space to address and heal from trauma. Block's stories do not necessarily rewrite specific literary fairy tales, but rather draw on various versions of a given fairy tale. The repertory into which they tap includes the well-known literary versions by Charles Perrault, Jacob and Wilhelm Grimm, Jeanne-Marie Leprince de Beaumont, and Hans Christian Andersen, as well as older versions, such as Giambattista Basile's, and new retellings and adaptations, including Walt Disney's animated films, and Angela Carter's and Neil Gaiman's famous rewritings. Like Carter's and Gaiman's, Block's stories highlight the disturbing, painful, and violent implications of some fairy-tale elements, as well as the crippling ideologies they convey to adolescents, especially young girls. They even tackle the same issues, although with their teenage audience in mind (whereas Carter's and Gaiman's texts are undoubtedly written for adult readers). Like Carter's 'The Bloody Chamber', Block's collection deals with pornography and its effects on women, although not in 'Bones', Block's rewriting of 'Bluebeard'2, but in 'Charm', a retelling of 'The Sleeping Beauty' tale; and Block's 'Snow', like Gaiman's 'Snow, Glass, Apples', addresses the problematically necrophiliac request of the prince in 'Snow White'.

While Carter's and Gaiman's texts introduce pornography and the Gothic into fairy tales to highlight their ideological violence, Block's The Rose and the Beast transposes nine well-known fairy tales into its contemporary framework, thus putting them into a new perspective. The historical context of Block's stories is indeed clearly the end of the twentieth and beginning of the twenty-first century, while the geographical setting, when it is identifiable, is undoubtedly southern California (Russell 2002, p. 109), and more specifically Los Angeles. Moreover, Block's take on the fairy tale is mostly realist, deleting or transforming their magical elements into modern and more plausible counterparts which draw out their dark implications (one striking example is the transformation of the needle of the spinning wheel from 'The Sleeping Beauty' tale into the needle of a drug 
syringe). As Vanessa Joosen notes, '[m]agic is one of the typical fairy-tale features that disappear or take on new guises in late twentieth-century retellings' (Joosen 2007, p. 228), and Block's collection is no exception. As it depicts, sometimes very crudely, 'a plastic, soulless society beset with drugs, sex, and violence' in which teenagers receive 'little help from the neurotic adult world' (Russell 2002, p. 107), The Rose and the Beast thus brings out and questions the disturbing and violent elements of the fairy tales it retells.

At the same time, the stories in The Rose and the Beast use the fairy-tale genre to show how difficult it is for adolescents to confront their violent and painful realities, as well as for teenage girls especially to find alternatives to the scenarios offered by many versions of the tales. In this sense, Block's stories provide safe spaces to confront all kinds of difficult realities and experiment with alternatives to them. Although all nine stories in The Rose and the Beast deal with the realities of a modern world for teenagers, the violence and pain of these realities is not always the same. Some stories unquestionably display characters living traumatic experiences (drug addiction and rape in 'Charm'; sexual abuse and murder in 'Wolf' ${ }^{3}$ and 'Bones'). Others represent the possibility of their heroines undergoing hurtful experiences, but ultimately allow them to be spared (this is the case in 'Snow' and 'Beast', in which both heroines avoid incestuous relationships). Others still depict the difficulties of leaving a well-known place, a home and a family, for example, to face the rest of society and live in a world in which one can get hurt in many ways (as in 'Tiny', 'Glass', 'Rose', and 'Ice'). Furthermore, the ways in which Block's protagonists cope with their respective realities also vary: some heroines are completely unable to face their difficult situations and hence mirror helpless fairy-tale heroines; others are unaware of the dangers they are in, which recalls the naiveté of many young girls in fairy tales; and others still attempt to free themselves more actively, thus breaking away from the scenarios offered by many well-known versions of the tales. The stories' depiction of the various types of sufferings, pain, violence, or traumatic experiences, as well as the heroines' diverse reactions to them, thus provide complex representations of adolescents' realities and ways of confronting them, all contained within the safe and exploratory spaces of Block's fairy-tale rewritings.

Furthermore, Block's stories also mobilize characteristic magical elements from the fairy-tale tradition to restore hope to their teenage heroines that sufferings can be overcome or at least come to terms with, and that healing from traumatic realities is possible. While the stories themselves are mostly realist, Block's language recreates the magical atmosphere of storytelling. Displacing the magic of the fairy tale from elements within the story to its language is identified by Joosen (Joosen 2007, p. 228) as a common strategy in contemporary rewritings and, indeed, as David L. Russell notes, Block's 'terse prose, which relies heavily on concrete imagery' is 'the perfect language for recreating the aura of the folktale' (Russell 2002, p. 108). This is also in line with Martine Hennard Dutheil de la Rochère and Géraldine Viret's argument that in Holocaust novels, it is the 'metaphoric language and vivid imagery' of fairy tales which 'allows [ ... ] to confront a reality which cannot be expressed directly' (de la Rochère and Viret 2011, p. 419; see also Landwehr 2009, p. 157). Unlike Holocaust novels which promise happy endings, however, Block's texts do not necessarily offer this possibility to their protagonists, as not all the stories in the collection end happily. Nevertheless, even in the most unhappy stories, there remains a magical element, as 'despair is warded off by love', although not, as Russell argues, the love we find in traditional fairy tales ${ }^{4}$, but one which 'begins deep within ourselves and moves onwards, supplying us the strength and confidence to face an indifferent, and sometimes treacherous, world' (Russell 2002, p. 114), as well as the most violent and painful realities.

In addition to the language and the strong presence of love, the emblematic figure of the magic helper also plays a vital role in restoring hope to Block's heroines. The figure of the helper is indeed present in all of the stories in The Rose and the Beast, although under various guises. Hilda Ellis Davidson argues that the figure of the helper is highly important in fairy tales because his or her 'intervention [ ... ] is essential to the plot, since this is what usually ensures that the final outcome is a happy one' (Davidson 2006, p. 99). In Block's rewritings, the intervention of the helper figure is indeed what brings hope to the suffering 
protagonist and hence is an essential part of the plot, too. While Davidson identifies that helpers in traditional fairy tales can be 'either animal or human, dolls or inanimate objects, the dead or supernatural beings' (p. 99), Block's stories more often than not have human beings as helper figures. These figures all help the heroines of Block's stories in various ways, which do not necessarily bring about the happy ending common in fairy tales, but provoke a usually beneficial change in the heroines' situations. Their interventions range from rescuing the heroine, providing shelter, comfort, and love, to forcing the heroine to confront her reality, or even a combination of all the above. Through the figure of the helper, the stories in The Rose and the Beast thus resituate the magic of fairy tales in human relationships, but the ambivalent roles of these helpers also attest to the complexities of confronting adolescents' violent and painful realities.

\section{The Rose and the Beast as a Collection of 'Anti-Tales' for Adolescents}

Many of the features of The Rose and the Beast outlined above point to the possibility of considering Block's stories as 'anti-tales'. According to Catriona McAra and David Calvin's definition of the term in their introduction to their volume Anti-Tales: The Uses of Disenchantment, the 'anti-tale' is '[r]arely an outward opposition to the traditional form itself', but it 'takes aspects of the fairy tale genre, and its equivalent genres, and re-imagines, subverts, inverts, deconstructs or satirises elements of them to present an alternate narrative interpretation, outcome or morality' (McAra and Calvin 2011, p. 4). McAra and Calvin further note that the 'anti-tale' features 'forms of (dis)enchantment [which] tend to be summoned as mirror images or coping mechanisms to deal with the social, political, and economic global realities at hand' (p. 5). In this sense, the term is appropriate to analyze Block's collection, which 're-imagines, subverts, inverts, deconstructs' violent and disturbing elements of fairy tales to call attention to them and their ideological implications, while also using the same fairy tales as 'mirror images and coping mechanisms' to address adolescents' violent, painful, and traumatic realities. Furthermore, McAra and Calvin list among the characteristics of the 'anti-tale' that it depicts 'lessons unlearnt', features a 'grey morality or amorality', and provides 'shifting perspectives' (p. 3). All these characteristics contribute to an understanding of the 'anti-tale' as a liminal story, which does not provide straightforward answers, but rather seeks to explore questions from various points of views. Block's stories likewise display such liminality in their use of motifs and symbols with different connotations (for instance, the awakening kiss at the end of 'Charm' is truly positive, while the one in 'Snow' is clearly incestuous), in their ambivalent portrayal of helper figures, and in their endings which are not necessarily happy but more often than not remain suspended. These 'grey' features in Block's collection contribute to the possibility of reading the stories as 'anti-tales'.

Considering Block's stories as 'anti-tales' draws attention to the fact that their narrative liminality mirrors the in-between state of their intended audience. Adolescence is indeed a liminal period of life, a passage from childhood to adulthood. As 'anti-tales', Block's stories are therefore particularly appropriate to address teenagers' complex realities, the difficulties of confronting them, and ways to re-enchant them. This is especially visible in the fact that they do not provide straightforward answers or morals but deal in 'lesson unlearnt' (McAra and Calvin 2011, p. 3), which is also a characteristic of young adult literature. Indeed, as she defines young adult fiction in her article 'Generational Collaborations in Emma Donoghue's Kissing the Witch: Old Tales in New Skins', in which she also analyzes Block's collection, Ann Martin points out that '[i]nstead of enforcing "conformity" through instruction', Donoghue's and Block's works reflect 'the "intellectual freedom" that young adult literature tends to encourage' (Martin 2010, p. 9). Similarly, Russell highlights that the themes which Block's stories deal with (he lists loss and recovery; self-discovery and self-actualization; and confusion) are the most common issues which adolescents have to face (Russell 2002, p. 108). Most tellingly, he further considers that 'Block takes stories that are, in the popular mind, most closely associated with early childhood and transforms them for the adolescent reader', the tales thus becoming 'bridges between childhood and 
adulthood-just as adolescence itself is a bridge' (p. 108). Block's stories as 'anti-tales' are indeed bridges, or in-between, liminal spaces which allow their adolescent heroines, and their readers, to confront violent, painful, disturbing, and traumatic realities, to experiment with alternatives to these realities, and to find hope that they can be come to terms with.

Because it cannot deal in appropriate depth with all nine stories in Block's collection, this article focuses on a selection of three stories, 'Charm', 'Snow', and 'Glass', which differ in the nature of the painful experiences they address, in their protagonists' ways of (not) confronting their realities, and in the role of the helper figure. 'Charm', 'Snow', and 'Glass' have also been chosen because many links are woven between them within Block's collection, in a similar way that the fairy tales they rewrite, 'Sleeping Beauty', 'Snow White', and 'Cinderella', mirror and echo one another within the fairy-tale tradition. 'Charm' transposes characteristic elements of the tale of 'Sleeping Beauty' into a modern Californian context and transforms them to address the unequivocally traumatic experiences of drug addiction and rape. Its heroine, Rev, is completely unable to face her reality, until a fairygodmother figure comes to her rescue. A rewriting of the tale of 'Snow White', 'Snow' develops the potentially unhealthy intergenerational relationships between the characters of the tale. The heroine is at first caught between her stepfather's incestuous desire and her mother's jealousy. Thanks to the loving background she has been provided with by her seven foster fathers, she is then able to face the situation and choose her own path in life, away from these intergenerational conflicts. Finally, 'Glass' uses Cinderella's willingness to do the house chores and her kindness towards her jealous stepsisters to address the difficulty but also the need to leave home and become part of the world. The heroine of this story is prompted by a fairy - the only fairy in Block's collection-to leave her seemingly satisfying situation and go out into the world, in order to develop a more genuine relationship with her sisters. Analyzing these three stories underlines The Rose and the Beast's complex use of the fairy tale to both address suffering and provide healing, highlighting in the process the liminal quality of Block's 'anti-tales' for adolescents.

\section{Sleeping Curses and Awakening Kisses: (Not) Confronting Drug Addiction in 'Charm'}

One of the most disturbing stories in The Rose and the Beast, 'Charm' uses the tale of 'Sleeping Beauty' to address the traumatic experiences of drug addiction, pornography, and sexual abuse. Block's rewriting transposes two of the most symbolic elements of the tale-the needle of the spinning wheel and the awakening kiss from the prince-into the modern world and develops their dark undertows to depict the traumas of Rev, a drug addict who is regularly gang-raped while her dealer, Pop, takes photos of the scenes. The story opens with an internal focalization on Rev who feels 'like the girl in the fairy tale. Maybe there had been some kind of curse. Inevitable that she would prick her arm (not her finger) with the needle' (Block 2000, p. 73). The parenthesis, which seems to want to correct the fairy tale, draws attention to the change made to it in Block's story: the image of the young girl 'prick[ing] her arm' immediately calls to mind a drug addict, reinforced by Rev's wondering if 'the girl [felt] this ecstasy of pure honeyed light in her veins, like being infused with the soul she had lost' (p. 73). In Block's modern-day American context, the needle of the symbolic spinning wheel from the fairy tale is transformed into the needle of the drug syringe, which in turn becomes a symbol of Rev's addiction, while the wicked fairy's magic curse of a hundred-years sleep is replaced by drug dependence and the passive state it causes, 'some kind of curse' (p. 73) in Rev's modern world.

Likewise, the prince's fascination with the sleeping girl and the ensuing awakening kiss (featuring in the Grimms' and Disney's versions) are transposed into the modern setting of Block's tale, and their sexual implications are made thoroughly explicit to represent pornographic $\operatorname{art}^{5}$ and sexual abuse. As the male character who is apparently in a relationship with Rev, Pop recalls the prince from the fairy tale, but he is quickly revealed to be an inversion of this figure as he furthers his most disturbing traits. Rev's dealer, Pop does not wake her up but he rather puts Rev in a sleepy or altered state of consciousness as 
'[h]e [gives] her what she need[s] in a needle in exchange for the photos he [takes] of her. And sometimes she [sleeps] with him' (p. 77). The awakening 'true love's kiss' of the prince from the fairy tale is thus replaced by sex in Block's story, which does not describe it in romantic terms. Furthermore, Pop has a macabre fascination for the passive and drugged Rev, whom he likes to photograph in various stereotypical guises, 'as witch, priestess, fairy queen, garden. He photographed her at the ruins of the castle and on the peeling, mournful carousel and in the fountain' (pp. 77-78). The roles and settings in which he takes his pictures deprive Rev of her own identity, as she becomes who he wants her to be. Most strikingly, he calls her 'Sleeping Beauty' and says, 'I like you this way' (p. 77), thus highlighting that he is attracted to her passive, sleeping or drugged, state.

Pop's pornographic endeavor is most visible in a scene that describes in gruesome details his use of Rev's body. At a party given by a movie star, Charm, he takes Rev upstairs to a bedroom and '[h]e [tells] her to take off her dress and arrange[s] her limbs on a big white bed, tie[s] and slap[s] her arm, tuck[s] the needle into the largest, least bruised vein. Then the three men climbed onto her while Pop hovered around them snapping shots' (p. 81). Rev is displayed in this scene, as Pop 'arranges her limbs' as he wants them 'on a big white bed' whose color is associated with purity, innocence, and virginity in fairy tales. This recalls Carter's Marquis in 'The Bloody Chamber' who fills the marital bedroom with white lilies, the flowers of chastity, to denote his young bride's virginity which he is going to pervert (Carter 2006, p. 10). Pop can similarly be seen as using the white bed to signal Rev's stereotypical innocence in his pornographic shots of her being gang raped. In addition, both Pop's pornographic pictures and the sexual abuse in 'Charm' are inspired by and developed from versions of the tale in which the sleeping princess is raped during her sleep. In Basile's version 'Sole, Luna e Talia' ('Sun, Moon, and Talia'), for example, a passing king finds Talia asleep. Her beauty having 'set him afire, [ ... ] he carried her in his arms to a bed, where he gathered the fruits of love and then left her asleep in the bed' (translated by Zipes 2001, pp. 685-86). Block's story thus transforms the one-time rape of the princess into repeated gang-rapes and the attraction of the passing king for the beauty of the sleeping girl into Pop's pornographic enterprise. In doing so, 'Charm' brings the sexual implications of the awakening kiss to the fore and uses them to address the contemporary issues of drug consumption, pornography, and sexual abuse.

While the use of fairy-tale elements allows Block's story to depict Rev's sufferings, her own identification with the fairy-tale heroine from 'Sleeping Beauty' makes her incapable of confronting them. Rev's use of the fairy tale of 'Sleeping Beauty' to make sense of her traumatic situation recalls the strategy used by Gemma in Yolen's Briar Rose. A Holocaust survivor, she transforms and retells the tale of 'Briar Rose' (or 'Sleeping Beauty') to remember her trauma herself and to communicate it to her granddaughters. While this strategy clearly has healing effects for Gemma, it functions in a more complex way for Rev. Even though it allows her to reflect on her situation within the safe framework of the fairy tale, it also imprisons her in its scenario. Rev indeed accepts her situation passively, because she believes she is cursed like the sleeping princess and has lost her soul. Rev associates herself to her city, like the princess is associated to her castle in the fairy tale, both being cursed and sleeping. The title of Perrault's version of the tale, 'La Belle au bois dormant' ('The Sleeping Beauty in the Woods'), even conflates the princess and the wood surrounding her castle, the adjective 'dormant' ('sleeping') situated next to the noun 'bois' ('wood') referring, according to French grammar, to the latter rather than to the 'Belle' ('Beauty') herself. Likewise, as she watches the city after it has been wrecked by an earthquake, Rev thinks: 'This is my city [ . . . ]. Cursed, like I am cursed. Sleeping, like I sleep. Tear-flooded and fever-scorched, quaking and bloodied with nightmares' (Block 2000, p. 75). Like the princess's castle and the wood surrounding it in the fairy tale, Rev's city is cursed and sleeping, but also the scene of natural disasters which echo Rev's own torments, her fever, shivers, and nightmares, due to her consumption of drugs. These echoes reinforce Rev's association of herself with the fairy-tale character and her belief that she is cursed. 
In addition to this belief, the reason Rev identifies for the curse, as well as her feeling that she has no soul, also prevents her from facing her reality. Throughout the story, Rev indeed wonders what may have caused her curse and concludes that it must be her beauty:

Was the curse that she was born too beautiful? Had it caused her real parents to abandon her, fearful of the length of lash, the plush of lip in such a young face? Was it the reason the men with cameras had sucked away her soul in little sips, because any form that lovely must remain soulless so as not to stun them impotent? Was it what made Old-Woman-Heroin's face split into a jealous leer as she beckoned Rev up to the attic and stabbed her with the needle that first time? (pp. 79-80)

It is clear that others are responsible for Rev's traumatic experiences: her parents gave her up for adoption, thus leaving her to her own means; men took pornographic pictures of her as a child to satisfy their own desires, thus depriving her of her soul and identity; the old woman administered heroin to Rev for the first time, thus turning her into a junkie. However, Rev identifies the reason for her dire situation in her own person, and even in her physical appearance, an aspect of herself she has little control over. Although she clearly sees that it is men's fear of being 'stunned impotent' that makes them want her to remain 'soulless', she accepts not to have a soul because it is easier and less painful. Thus, as the three men rape her and Pop takes pictures, she 'lay still. She let the opium be her soul. It was better than having a soul. It did not cry out, it did not writhe with pain' (p. 81). Rev here refuses to face her situation because of the pain it would entail to do so. Even if she sees being drugged, gang-raped, and used as a model for pornographic pictures as a curse, she is not able to try and break it as she knows how violent and painful that would be. Using its heroine's identification with the cursed princess, 'Charm' thus highlights the difficulty of confronting painful realities for adolescents once they are deeply ensnared within them and even believe some of their sufferings are their fault.

As it uses well-known fairy-tale elements to address Rev's sufferings and to highlight her difficulties in confronting her traumatic reality, Block's story also draws on the specific character of the fairy godmother and her role within the tale to provide hope that life's ordeals can be overcome. Indeed, the fairy godmother from the tale of 'Sleeping Beauty' becomes a prominent figure in 'Charm', a modern and independent woman who saves Rev and provides her with a safe house and companionship. In opposition to many versions of the 'Sleeping Beauty' tale, Rev is not rescued by the prince, who on the contrary turns out to be her oppressor, but by a woman. In this sense, Block's tale aligns itself with other feminist revisions of 'Sleeping Beauty' which, as Carolina Fernández Rodríguez has shown, 'attempt, on the one hand, to demythologize the traditional hero, and, on the other, to offer different alternatives to it' (Rodríguez 2002, p. 52); these alternatives include 'first, female cooperation [ ... ]; second, self-liberation; and third, homosexual relationships' (p. 57). The woman who rescues Rev in 'Charm' specifically mirrors the fairy godmother from Perrault's 'La Belle au bois dormant' ('The Sleeping Beauty in the Wood'). Contrary to the traditional image of the fairy godmother, who is 'usually elderly rather than young' (Davidson 2006, p. 104), Charm is a 'young woman' with 'shorn black hair and pale skin' (Block 2000, p. 82) ${ }^{6}$. She thus recalls Perrault's 'young fairy' (translated by Zipes 2001, p. 689) who saves the princess from the old fairy's death curse. Charm's first appearance in Block's story indeed mirrors that of the young fairy in Perrault's text. After the old fairy has cursed the princess and the whole court is in a great distress, the young fairy suddenly 'step[s] out from behind the tapestry and utter[s] [ ... ] in a loud voice' (p. 689) the words which convert the death curse into a sleep curse, thus saving the princess's life. Likewise, as Rev is being abused by the three men while Pop takes pictures of them, Charm unexpectedly appears in the bedroom, 'scream[ing] like the soul Rev no longer had' (Block 2000, p. 81) and drives the men away with 'a small sharp kitchen knife' (p. 82). Even though Perrault's fairy uses magic and Charm an ordinary utensil, both their interventions are somewhat sudden and providential. In this sense, Block's story modernizes the figure of the fairy godmother and her interference but keeps the hope it brings to the desperate situation. 
Hope is further brought to Rev by Charm, as she takes care of her while she battles her drug addiction, in a similar way that Perrault's fairy looks after the sleeping princess. Indeed, Perrault's fairy is not only present at the princess's christening to save her life, but she comes back when the princess pricks her finger on the spindle and falls asleep. At this moment, she takes precautions to make the princess's hundred-year sleep safe and as pleasant as possible. First of all, she puts everyone in the castle to sleep so that the princess will not find herself alone when she wakes up but surrounded by people ready to wait on her. Then, she protects the sleeping princess by surrounding the castle with 'a great quantity of trees, large and small, interlaced by brambles and thorns' (translated by Zipes 2001, p. 690). Finally, as we learn when the princess wakes up, she 'procure[s] her the pleasure of very agreeable dreams during her long slumber' (p. 693). Likewise, Charm does not only save Rev from her dealer and rapists, but she is also a benevolent presence throughout Rev's detoxifying sleep. Charm allows Rev to stay at her place as long as she wants and needs. To heal from her drug addiction, Rev sleeps

for days and days. Sometimes she woke kicking her legs and feet until the comforter slid from the bed. Then she would feel someone covering her with satin and down again, touching her clammy forehead with dry, soft, gardenia-scented fingertips. Sometimes she woke shivering, sweating, quaking or parched. Always the hands would be there to warm or cool or still her, to hold a shimmering glass of water to her cracking lips. (Block 2000, pp. 89-90)

Rev's sleep is not as pleasant as the Sleeping Beauty's—she has nightmares-but Charm, like the fairy in Perrault's version of the tale, is always present and always seems to know what Rev needs, in a similar way that the fairy anticipates the young princess will need her servants when she wakes up. Charm's role is therefore crucial, not only because she saves Rev on one occasion but because she remains in the story, always there when Rev needs her, and because she helps her face the reality of her drug addiction and take steps towards her detoxification.

Charm's role is also crucial in that she provides companionship and love, alternatives to the oppressive and abusive relationship Rev had with Pop. Like the fairy in Perrault's tale, who is present at two significant moments of the princess's life-her christening and her pricking her finger on the spindle-Charm is also present in both Rev's youth and during her detoxification. Indeed, Charm reveals to Rev that they know each other, grew up together for a while, and even suffered the same abuses. She shows her a photograph her stepfather took, on which there are 'two naked young girls, one dark, one pale, curled on a leopard-skin sofa. Their hands and feet were shackled together. It was herself and the woman' (p. 94). Rev then remembers that she had a best friend when she was young, the only person with whom she could be happy as they helped each other out to live through the same pains. Not only was Charm abused and used for pornographic pictures like Rev, but she also used to be a drug addict, as she says to Rev: 'If you need it I'll get it for you. Until you decide you want to stop. I stopped' (p. 89). Charm therefore offers Rev understanding since she knows exactly what she is going through and companionship like the one they had as children. The story ends with a rewriting of the awakening kiss from the 'Sleeping Beauty' tale: the fairy-godmother figure kisses the already awake young girl and ' $[w]$ hen Charm kisse[s] her, Rev [feels] as if all the fierce blossoms were shuddering open. The castle was opening. She [feels] as if the other woman were breathing into her body something long lost and almost forgotten' (p. 97). The image of the cursed castle is present again, but this time it positively opens up, as Charm's kiss gives Rev her soul back and awakens her to a re-enchanted life, in which drugs and rapes have been replaced by shared experience and love.

\section{Poisoned Apples and Pairs of Boots: (Not) Facing Intergenerational Conflicts in 'Snow'}

The first story in The Rose and the Beast, 'Snow' is Block's take on the tale of 'Snow White', which is used to address unhealthy intergenerational relationships. Like 'Charm', 
'Snow' transposes core elements from the fairy tale-the hunter's sparing of Snow's life, the prince's desire to have Snow White's glass coffin, and the stepmother's jealousy-into its contemporary world, transforms them, and uses them to depict complex intergenerational relationships which involve incest and female rivalry. The central theme of the 'Snow White' tale is often considered to be female jealousy and rivalry, or as Bacchilega aptly puts it, 'Snow White' is a 'narrative of female development' in which 'jealousy seems a necessary ill' (Bacchilega 1997, p. 31). However, although Snow's mother's jealousy is a key element in Block's rewriting, it is not the prime focus of the story as it is supplanted by the disturbing desire of the father figure for the young girl. The opening of the story clearly underlines such a focus: whereas the mother's jealousy is absent from the scene, the gardener's troubling desire for the baby girl is put to the fore, thus laying the ground for the treatment of incestual relationships.

The opening of Block's story indeed presents Snow's mother as a positive counterpart to Snow White's stepmother, while the gardener, a modern version of the huntsman, is a more ambiguous character than his fairy-tale counterpart. Snow's mother is depicted as a woman 'so young, still a girl herself [who] [doesn't] know what to do' (Block 2000, p. 3) with her new-born child. Knowing she is incapable of taking care of the baby who does not stop crying, Snow's mother gives her to the gardener. At this moment, there is no jealousy or rivalry in their relationship, just a hint at Snow's mother's unwanted teenage pregnancy. The gardener, however, takes the child but quickly realizes that he, too, cannot keep her, as '[h]e imagine[s] her growing up, long and slim, those lips and eyes' (p. 5). While Rev in 'Charm' wonders if her own parents have given her up for adoption because she was too beautiful a baby with her long lashes and plush lips, it really is Snow's 'lips and eyes' that prompt the gardener to bring her to the seven brothers who live in the canyon. As Jeana Jorgensen rightly comments, 'the gardener in Block's story "Snow" does not trust himself to raise the infant protagonist because he can picture what she will look like when she grows up' (Jorgensen 2019, p. 267) and he knows he will be attracted to her. As he saves the baby from his own disturbing attraction by bringing her to the seven brothers' house, he mirrors the huntsman of the Grimms' tale who spares Snow White's life, leaving her in the woods in which she finds the seven dwarfs' home. In turn, the gardener's fascination with the baby's beauty in Block's story draws attention to the fact that the huntsman also takes pity on Snow White because she is 'so beautiful' (translated by Tatar 1999, p. 84) although she is only 'seven years old' (p. 83) in the Grimms' version of the tale. Block's tale thus develops the dark undertows of the traditional fairy tale and uses them to address a potentially disturbing relationship between an adult man and a very young girl.

The exploration of this disturbing relationship is further carried out when the gardener abandons the role of the huntsman and takes on that of the prince, although he already is Snow's mother's partner. Even though he does the right thing when she is a baby, the gardener cannot, however, help come visit Snow when she is grown up, to see 'if he had been right when he saw her baby face and imagined it grown, and knew he could not keep her' (Block 2000, pp. 13-14). He is immediately seduced by her and although he wonders why he has come the first time, he then repeatedly visits her and spends time with her. The disturbing implications of the gardener's attraction to Snow are further developed in the story when he is called by the seven brothers after Snow bites into the poisoned apple. Like Gaiman's 'Snow, Glass, Apples', this scene in Block's story indeed brings out the necrophiliac undertones of the prince's request to the dwarfs for Snow White's glass coffin in Grimms' version of the tale. While the prince assures the dwarfs that he 'will honor and cherish her as if she were [his] beloved' (translated by Tatar 1999, p. 89), the gardener feels, as he observes the comatose Snow, that '[h]e want[s] this stillness. She was completely his, now, in a way she would never be again. His silent, perfect bride' (Block 2000, p. 29). The gardener's attraction to Snow's 'stillness' and 'silence', the fact that he thinks she is 'completely his' and that he 'want[s] to possess' (p. 29) her not only highlight the necrophiliac character of the scene from 'Snow White', but also that the gardener's incestuous desire for Snow has always been highly unhealthy. Even though he is 
the one to wake her up with a kiss, it is, as Russell argues, 'a kiss not from Prince Charming but from a lustful older man who is also her stepfather. The awakening kiss is an incestuous kiss' (Russell 2002, p. 109). Like 'Charm', 'Snow' thus explores the sexual implications of the scene of the awakening kiss to address this time the issue of intergenerational incest.

Intergenerational relationships are further complicated in 'Snow', as it is the gardener's attraction to the young girl which provokes her mother's jealousy and her poisoning which sends the gardener to Snow's bedside. In many versions of the tale, especially the Grimms' and Disney's, it is 'the heroine's exceptional beauty [which] sets in motion the drama of jealousy' (Bacchilega 1997, p. 31) ${ }^{7}$. In Block's rewriting, however, Snow's mother's jealousy only arises when she sees her daughter with her own partner. There is an emphasis on Snow's physical appearance in this scene, as her mother thinks: 'The girl was nightmare. Young young young. Silver white. Perfect. Untorn. Perfect' (Block 2000, p. 20). However, the focus is not on Snow's beauty, but rather on her youth, the adjective being repeated thrice, and her virginity denoted by the color 'silver white' and the adjective 'untorn'. The mother knows that these traits are what draws the gardener to Snow, and they hence foster her jealousy, which becomes understandable and even relatable. The mother's jealousy then pushes her to attempt to kill her own daughter, repeating the scene which Joosen identifies as the 'most often left unchanged' (Joosen 2007, p. 234) in contemporary retellings of the tale: Snow White's biting into the poisoned apple and falling into a deep sleep. Snow's mother indeed brings her daughter 'apples injected with poison. She had read about it-simple recipe' (Block 2000, p. 21). After biting into one of the apples, Snow falls into a deep sleep, a kind of coma, as noted by Joosen (Joosen 2007, p. 234), since she still has a faint pulse. Although she succeeds in poisoning her daughter, Snow's mother immediately regrets it and comes home to the gardener 'screaming [ ... ] what have I done?' (Block 2000, p. 29), thus highlighting her complex feelings towards her daughter. And paradoxically, although she wanted to prevent her from being with the gardener, it is the mother's poisoning of her daughter which sends him to Snow's bedside to wake her up. Block's story thus depicts a complex triangular intergenerational relationship which cannot be reduced to female jealousy, as it also addresses incest between parents and children and its intricate implications.

As in 'Charm', the fairy tale is also used in 'Snow' to depict the difficulty of the heroine to face this complex intergenerational conflict. Although she does not identify with her fairy-tale counterpart like Rev does, Snow's reactions recall Snow White's characteristic naiveté, while episodes of the Grimms' fairy tale are used as warnings that she ignores. The young Snow has been sheltered all her life by the seven brothers who raised her and hence she has never met any other human beings or needed to interact with them. She therefore struggles to make sense of her own feelings towards both the gardener and her mother. After the gardener's first visit, she cannot go to sleep and seeks to understand her own desires. Once she does fall asleep, she has a nightmare about the gardener, which echoes the huntsman taking Snow White to the woods in the fairy tale. Like the huntsman who is described as 'pulling out his hunting knife and about to take aim at [Snow White's] innocent heart' (translated by Tatar 1999, p. 84), Snow dreams that the gardener is 'carrying the body of a very pale child into the woods and holding the ax ... ' (Block 2000, p. 18). In 'Snow', the fairy tale therefore acts as a warning for the heroine, who then struggles with her feelings of wanting to see the gardener and yet knowing there is something wrong with seeing him. She follows her desires, however, and continues to see the man. Similarly, Snow is troubled during her mother's visit because she feels that she recognizes her and this pushes her to ignore all the warnings the brothers have given her, like Snow White does in the Grimms' tale. Indeed, even if the dwarfs repeatedly warn Snow White 'to be on her guard and not to open the door to anyone' (translated by Tatar 1999, p. 87), she is not 'the least suspicious' (p. 86) or 'suspect[s] nothing' (p. 87). Likewise, Snow knows that the seven brothers have told her 'not to let strangers in' (Block 2000, p. 22) and 'not to accept gifts from strangers' (p. 23), but she feels that the woman is 'not a stranger, this [is] someone she sense[s] deep in her bones' (p. 22) and 'a woman who seem[s] familiar' (p. 23). 
Snow is not as naïve as her fairy-tale counterpart, but her ignorance of the world outside her home makes her incapable of identifying the dangers as she is trying to understand her own feelings, and she takes the poisoned apples her mother is giving her.

As for Rev, it is the benevolent presence of helper figures, the seven brothers, which finally helps Snow face reality and choose her own path, away from the intergenerational conflict created by her mother and the gardener. Her seven foster fathers can be seen as responsible for her incapability to face the outside world since they are the ones who kept her sheltered in their house. However, their discreet presence as well as the understanding and freedom they give Snow help her face her situation. The seven brothers are indeed here for Snow after her first meeting with the gardener and her nightmare about him the following night. Far from discouraging her from meeting men, they try 'to console her, seven brothers, as seven fathers would. They tried to be fair; how could they keep her from living her life?' (p. 18). They are conscious that she needs to go into the world, live her life, meet men, even though they do not want her to get hurt. Although they say that maybe they could find another man for her, they tell her she can meet the gardener again, thus leaving the choice entirely up to her. As Jorgensen aptly puts it, they 'know enough to understand that they cannot hang on to her and deny her nascent sexuality forever' (Jorgensen 2019, p. 266). Like Charm, who agrees to get Rev the drug that she needs until she herself decides to stop, Snow's seven fathers leave her the choice of remaining in a relationship with the gardener and support her. They even are the ones who call the gardener after Snow bites into her mother's poisoned apple and falls into a coma. They are therefore not the ones to physically save Snow, unlike Charm who appears with a kitchen knife to save Rev, but they are the same discreet presence as Charm is for Rev. Such presence, as well as her relationship with them, is what ultimately helps Snow.

The seven brothers' relationship with Snow is indeed also crucial as it provides her with an example of a relationship which is the opposite of the complex intergenerational conflict her mother and the gardener have caught her in. In their interaction with Snow, the seven brothers mirror the seven dwarfs from 'Snow White' while also being more developed and more modern versions of them. In the Grimms' tale, the dwarfs promise Snow White to 'give [her] everything [she] needs' if she agrees to 'cook, make [their] beds, wash, sew, knit' (translated by Tatar 1999, p. 85) for them. On the contrary, the seven brothers pose no conditions and simply give Snow everything they can. When she is a baby and a young child, this includes a room, clothes and shoes, healthy food (Block 2000, pp. 9-10), books and music (pp. 15-16). She also learns not only how to cook and sew, but also how to garden and build like the brothers themselves (p. 11). Unlike her fairy-tale counterpart, Snow also knows how to do the same manual work as the brothers, who themselves also cook, sew, and knit. Her relationship with them is thus a reciprocal one, unlike the arrangement Snow White has with the dwarfs in the fairy tale. Furthermore, as she grows up and becomes a woman, the brothers worry about it 'a bit' but learn 'how to show her as much love as they had when she was a baby and yet give her a distance that was necessary for them as well as for her' (pp. 10-11). Like the gardener, the brothers are worried about loving Snow when she grows into a woman, but contrary to the gardener, they change their relationship with her, so that it remains reciprocal and in tune with everyone's needs ${ }^{8}$. Thus, the presence of the seven brothers in Snow's life provides her with an example of healthy relationship which ultimately helps her understand the intergenerational conflict she is caught in. Indeed, like Rev who overcomes her drug addiction by sleeping it off, Snow seems to ponder her situation and come to a decision while she is asleep: 'In her sleep she had seen love. It was poisoning. It was possessing. Devouring. Or it was seven pairs of boots climbing up the stairs to find her' (pp. 30-31). Snow now identifies her mother's love as poisoning, the gardener's love as possessing, and both as devouring. In the end, she chooses the seven brothers' love which is made of the simple things of life, comfortable boots and rushed footsteps that testify to their affection for her and the healthy relationship they have developed. 


\section{House Chores and Glass Shoes: (Not) Living in the World in 'Glass'}

Perhaps one of the most symbolic stories in The Rose and the Beast, 'Glass' retells the tale of 'Cinderella' to depict the difficulties of going out into the world and living in it. Like 'Charm' and 'Snow', Block's story uses elements from the fairy tale-Cinderella's house chores and her care of her stepsisters, as well as the ball scene-to depict the heroine's satisfaction with her situation, but also her fear of being hurt and her attempt to escape living in the world. Unlike many of the other stories in The Rose and the Beast, 'Glass' opens on a heroine who is happy and fulfilled. Drawing on the fact that Cinderella remains kind, does all that she is asked (notwithstanding her disobedience when she goes to the ball), and never complains, neither in Perrault's nor in the Grimms' version of the tale, 'Glass' depicts a heroine satisfied with her role within her household from the very beginning. An internal focalization shows her fondly thinking about the house chores she must do:

And she had the tasks. She loved to plant the beds with lilies and wisteria, camellias and gardenias, until her hands were caked with earth. To arrange the flowers in the vase like dancing sisters. To make the salmon in pomegranate sauce; the salads of spinach, red onion, pine nuts, oranges, and avocados; the golden vanilla cream custards; the breads and piecrusts that powdered her with flour. She loved, even, to dust the things, to feel them in her hands, imagining their history. (Block 2000, pp. 56-57)

Gardening, cooking, and even cleaning the house are enjoyable activities for this Cinderella figure. Her having hands 'caked with earth', being 'powdered [ ... ] with flour', or covered in 'dust and ash and flour and mud' (p. 62) is no longer a symbol of her role of servant but a sign of her creativity. She indeed invents flower arrangements and recipes and imagines the stories of the objects she dusts. 'Glass' thus transforms Cinderella's house chores and her dirty appearance which imprison her in the fairy tale into meaningful and empowering traits which account for the heroine's satisfaction with her life.

In addition, Block's heroine is also happy in her relationship with her sisters, as she loves to take care of them. Her ability to make other people feel good, physically as well as mentally by telling them stories, is enough for her to feel fulfilled. Thus, when her sisters come back home in the evenings, '[a]lways she would tell them stories; they returned at night and sat before their mirrors, let her rub their feet with almond oil, soothe them with her words and in this way she felt loved' (p. 59). Soothing both her sisters' bodies and minds is her way of finding her own purpose and satisfaction in her life. Karlyn Crowley and John Pennington convincingly argue that, by making her heroine a storyteller and 'altering the teleology of the tale by freeing the protagonist from the beginning rather than postponing freedom to the end, Block enables Cinderella to tell a different story' (Crowley and Pennington 2010, p. 308). This different story indeed removes the mistreatments Cinderella's stepsisters subject her to and her slaving condition in her own home, present in the versions of the fairy tale by Perrault, the Grimms, and Disney. Instead, Block's story is that of a content young woman for whom house chores and taking care of others are meaningful sources of happiness and love ${ }^{9}$.

However, even though the heroine is satisfied with her sisterly relationship, Block's story nevertheless suggests that it is not a healthy one and develops the jealousy of Cinderella's stepsisters. Although the heroine of 'Glass' is happy to tell stories to her sisters, she realizes that these stories are what make her sisters 'love her. Or need her at least' (Block 2000, p. 56). The addition, as an afterthought, introduces a trace of doubt in the heroine's thinking and a qualification of the kind of love her sisters give her. Furthermore, when the Cinderella figure does go out of her house into the world and meets a young man who only looks at her, the sisters immediately 'eye[ ... ] her jealously, secretly' (p. 64). Their jealousy, like Snow's mother's, is more relatable than in the fairy tale, as it is not due to the heroine's beauty but her creativity. The sisters indeed think that 'they ha[ve] stories, too, they'd like to tell' (p. 64). Even though they enjoyed the stories that the heroine told them, maybe they always felt the need to tell their own stories as well, thus making the relationship not an entirely happy one. While it transforms Cinderella's stepsisters who are awful with her in the fairy tale into sisters who need the heroine, Block's story nevertheless 
retains their jealousy whose latent presence makes the relationship not necessarily as good as the heroine wants to believe.

In addition, it quickly becomes clear that Block's Cinderella figure likes to remain at home because she is afraid of having to go out into the world, as testified by the story's take on the ball scene of the traditional fairy tale. The opening of 'Glass', with its internal focalization on the character, depicts the heroine thinking that she does 'not mind her days alone, away from the eyes outside' and that it is 'better this way, her secret stories hidden so no one could touch them, take them' (p. 55). Tellingly, she does not think that she loves being alone, but that she does 'not mind' it, which is an ambiguous formulation, while the phrase 'away from the eyes outside' highlights her fear of being seen. She also clearly wants to protect her stories, to keep them for herself and her sisters, who only 'listen[ ... ], rapt, but [do] not take' (p. 55) her stories. She further pictures the outside world as a place in which people are obsessed with beauty, a fact that she does not understand: 'the eyes and ears and the mouths whispering-beautiful, beautiful, why did it matter she wondered' (pp. 55-56). Her picture of the outside world strongly recalls that of the crowd at the ball in Perrault's 'Cendrillon ou la petite pantoufle de verre' ('Cinderella; or, The Glass Slipper') when Cinderella first enters the room: everyone is 'engrossed [ ... ] in regarding the beauty of the unknown lady. Nothing was heard but a low murmur "Oh, how lovely she is!"' (translated by Zipes 2001, pp. 451-52). As Perrault's text focuses on people looking, hearing, and murmuring, Block's story represents the crowd by the metonymies of 'eyes', 'ears', and 'mouths', creating a creepier effect which reinforces the heroine's fear. Using and transforming the famous scene of the ball into a more disturbing crowd, Block's story thus represents the heroine's impression of the world and hence her difficulty to go out into it.

It is the intervention of a fairy godmother which will force the heroine to face her fears and go out of her comfortable situation, although with unpleasant consequences at first. Like Charm, the fairy godmother in 'Glass' appears out of nowhere, not to save the heroine but to push her into leaving her home. Unlike Charm and the seven brothers in 'Snow', this fairy godmother does not remain in the story as a comforting presence. Her role is actually very ambiguous: she does not come across as a benevolent woman helping a girl in distress, and her intervention actually disrupts the balance of the heroine's life. Block's story announces her arrival with the sentence 'But the woman came to her then' (Block 2000, p. 59). The use of the conjunction 'but' makes it clear that the fairy's arrival is a turning point in the heroine's life and maybe not an entirely good one. Indeed, the heroine follows the advice or even the orders (the fairy repeatedly uses the phrase 'you must' (p. 61) or imperatives to address the Cinderella figure) of the fairy and leaves her home to go out into the world, although this makes her lose her abilities as a storyteller. As she feels her sisters' envy, '[t]he story end[s], she [cannot] tell the rest, they'd hate her' (p. 65). She runs home 'through a tangle of words where the letters jumbled and made no sense and meant nothing, and the words were ugly' (p. 66). As in the traditional fairy tale she loses one of her glass slippers, but in Block's version, this slipper is 'like a dropped word lost, like the word, the missing word to make the story right again, to make it complete' (p. 67). The very famous run home and the loss of the glass slipper from the fairy tale become in Block's story the symbols of the changed life of the heroine, who loses one of her most important abilities. The fairy godmother's intervention, therefore, although it pushes the heroine to face her fears, does not appear beneficial at first.

However, it is this intervention which allows the heroine and her sisters to develop a healthier and more equal relationship after the events of the dance, thus highlighting once again the vital role of the helper figure. As in Perrault's and the Grimms' version of the tale, the young man the heroine met at the dance comes to find her 'even without her enchantments, her stories, her dress, her shoe' (p. 68). When the sisters see his determination, they seem to understand the situation and to come to terms with their envy. As they watch him kneeling in front of the heroine and offering her the shoe, 'they [know] that if they tried to take this from her they would never know, have nothing left, they 
would starve, they would break, they would never wake up' (pp. 69-70). The sisters seem to understand that their own fulfilment depends on them letting the heroine be happy, as her happiness and ability to tell stories will in turn make them content. At this moment, the fairy godmother reappears in the story, but not for the heroine, for the sisters and tells them: '[y]ou must reach inside yourselves where I live like a story' (p. 70). The fairy tells them that they, too, have the ability to tell their own stories and that they must cultivate it. This ending is in complete opposition to those of the Grimms' and Perrault's versions of the tale. While the Grimms' ending displays punitive violence (Harries 2005, p. 55) and the stepsisters have their eyes pecked out by birds, Perrault's focuses on Cinderella's kindness as she forgives her stepsisters and marries them to wealthy men. On the contrary, Block's ending does not punish or redeem the sisters, but gives them agency by making them the heroines and tellers of their own individual stories. Thus, the fairy's intervention is beneficial for all female characters, as it pushes the heroine to face her fears of the world and her sisters to realize that they needed to tell their own stories, too. All of them can now start to build a more equal and healthier relationship. In 'Glass', therefore, the intervention of the helper figure is not only crucial for the heroine of the story but for the other female characters as well.

The focus on the heroine and her sisters at the end of the story reflects the complex treatment of the idea of confronting reality through fairy tales in 'Glass'. Indeed, unlike Rev who is clearly living a traumatic experience or Snow who is potentially on the edge of living one, the Cinderella figure in 'Glass' more symbolically and more generally needs to go out into the world and live in it, in interaction with other people, which can be hurtful but also fulfilling, and much more fulfilling than remaining alone at home to take care of her sisters. This is most apparent when the fairy gives the heroine 'glass shoes' (p. 61), the most famous symbol in the 'Cinderella' tale. These shoes, however, are not made by magic, they are 'made of [the heroine's] words, the stories [she] has told' (p. 61). The fairy further warns the heroine that ' $[t]$ he shoes are for dancing not for running away' (p. 62). Crowley and Pennington analyze this warning as 'the godmother tell[ing] Cinderella that she cannot run away from the fairy tale-she must confront the tale head-on' (Crowley and Pennington 2010, p. 308). Not only must she confront the tale head-on, but she must also confront reality head-on, and accept that she will get hurt, but that she will also develop healthy and reciprocal relationships with other people as they exchange their respective stories. As Crowley and Pennington very well state, '[t]he story's title, "Glass," reaches beyond the traditional slipper to reflect the fragility of all the characters who desire companionship and love' (p. 310). It also reflects the fragile balance in human relationships between need and envy, love and hate, violence and care.

\section{Conclusions}

As a whole, Block's collection of stories reflects a fragile balance in its use of the fairytale genre to both address the violence, pain, and traumas of adolescents' realities, and to provide hope and possibilities of healing. On the one hand, as the stories in The Rose and the Beast retell well-known fairy tales to represent the violent and painful realities teenagers can be faced with in the modern world, they draw attention to the literal and ideological violence inherent in the fairy tales themselves, as well as to the difficulties of confronting realities and finding alternatives to the often-disabling scenarios provided by well-known versions of the tales. On the other hand, the framework of the fairy tale as an imaginary story allows the heroines to reflect on their realities and to explore new possibilities in a safe space, while the presence of helper figures restores hope that difficulties can be overcome and that it is possible to heal from traumas. In their negotiation of such fragile balances, Block's stories can be read as 'anti-tales', tales which feature ambivalent characters and shifting perspectives, and which do not provide ready-made answers to difficult situations but foster reflection. Block's 'anti-tales' are liminal stories which mirror the in-between stage of life of their intended adolescent audience, and this is most visible in their endings. While most of them are 'satisfying' and 'validate the protagonists' choices' (Martin 2010, 
p. 11), they nevertheless all remain suspended in time. 'Charm' ends on a first kiss, the beginning of a new relationship; in 'Snow,' the seven brothers are coming up the stairs but have not yet reached Snow's room; and when the fairy leaves at the end of 'Glass', the Cinderella figure still has not finished telling her story and her sisters have not uttered the first words of theirs, either. These suspended endings which lead to new stories mirror adolescence as a passage from childhood to adulthood. Block's 'anti-tales' have provided their heroines, and their readers, with liminal safe spaces to confront their realities, learn, grow, and find magic again, and they can now re-enter the world with new knowledge, which will help them continue to confront and re-enchant their realities, even as adults.

Funding: This research received no external funding.

Institutional Review Board Statement: Not applicable.

Informed Consent Statement: Not applicable.

Data Availability Statement: Not applicable.

Acknowledgments: I would like to warmly thank the editor of the present special issue, Susan Redington Bobby, for her availability and enthusiasm about my project.

Conflicts of Interest: The author declares no conflict of interest.

\section{Notes}

1 Even the classic 'true love's kiss' scenario (featured in Disney's adaptation of the 'Snow White' tale, as well as in the Grimms' and Disney's versions of 'The Sleeping Beauty' tale) has been rethought as more problematic than it seems in light of recent discussions about consent.

2 Block's 'Bones' resembles Carter's 'The Bloody Chamber' in that it also refocuses the tale on the husband's murders. Block's Bluebeard figure is indeed a serial killer who murders lonely young girls in his Los Angeles's mansion.

3 For an analysis of sexual violence and female agency in 'Wolf', see Elizabeth Marshall's article 'Girlhood, Sexual Violence, and Agency in Francesca Lia Block's “Wolf"' (Marshall 2009, pp. 222-26).

4 Love in Block's collection can also take many forms (romantic, familial, friendly, homosexual), which testifies to a complex engagement with the traditional happy ending of fairy tales. Cristina Bacchilega for instance reads the story 'Rose' as underscoring the sisters' 'intimate bond-its queerness tugging at the tale's heteronormative ending' (Bacchilega 2015, p. 90), while Ann Martin argues that 'the final scene of "Charm" undermines the centrality of heterosexual desire that is often found in versions of "Sleeping Beauty"' (Martin 2010, p. 11).

5 The association of pornography with the tale of 'Sleeping Beauty' is not new. As Elizabeth Wanning Harries notes, '[v]ersions of "Sleeping Beauty" have often verged on the obsessive and pornographic' (Harries 2011, p. 366): from nineteenth-century illustrations to fashion photography.

6 Charm's black hair and pale skin also recall the famous description of Snow White. The tales of 'Sleeping Beauty' and 'Snow White' are often associated in the fairy-tale tradition as both feature sleep curses and the awakening of the young woman. 'Charm' similarly has its two heroines be drug addicts and live through the same abuses, its ending opening up the possibility that Sleeping Beauty and Snow White could form a couple after having lived through the same experiences.

7 Cristina Bacchilega further claims that this is why critics have focused 'on the magic mirror so insistently' (Bacchilega 1997, p. 31). One of the most famous symbols of the 'Snow White' tale, the magic mirror is indeed the one to put Snow White and her stepmother in a competition to be the fairest. It is interesting to note that this motif is completely absent from Block's rewriting, the connection between Snow's beauty and her mother's jealousy being thus further severed.

8 Analyzing the representation of masculinity in contemporary American retellings of fairy tales, Jeana Jorgensen also opposes the gardener and the seven brothers in Block's story, arguing that the gardener is a representative of patriarchy while the brothers are 'kind, gentle, and loving, thus establishing a spectrum of masculinity' (Jorgensen 2019, p. 267).

9 Transforming Cinderella's house chores into meaningful work is a strategy also used by Rebecca Solnit in her recent story Cinderella Liberator (Solnit 2019). Solnit writes in her afterword that '[w] hen it came time to write her story for our time, it seemed [... ] that the solution to overwork and degrading work is not the leisure of a princess, passing off the work to others, but good, meaningful work with dignity and self-determination' (Solnit 2019, p. 30). Her Cinderella, who enjoys baking, therefore opens a cake shop. Such reflections on alternatives to 'overwork and degrading work' are also present in Block's story, as her Cinderella figure does not become a princess either (the young man she meets at the party is never designated as a prince) and it is her creativity in all the aspects of her work which is her strength in her own modern society. 


\section{References}

Bacchilega, Cristina. 1997. Postmodern Fairy Tales: Gender and Narrative Strategies. Philadelphia: University of Pennsylvania.

Bacchilega, Cristina. 2015. Fairy-Tale Adaptations and Economies of Desire. In The Cambridge Companion to Fairy Tales. Edited by Maria Tatar. Cambridge: CUP, pp. 79-96.

Block, Francesca Lia. 2000. The Rose and the Beast: Fairy Tales Retold. Joanna Cotler Books. New York: Harper Collins.

Carter, Angela. 1994. American Ghosts and Old World Wonders. London: Vintage.

Carter, Angela. 2006. The Bloody Chamber and Other Stories. London: Vintage.

Crowley, Karlyn, and John Pennington. 2010. Feminist Frauds on the Fairies? Didacticism and Liberation in Recent Retellings of "Cinderella". Marvels \& Tales 24: 297-313.

Davidson, Hilda Ellis. 2006. Helpers and Adversaries in Fairy Tales. In A Companion to the Fairy Tale. Edited by Hilda Ellis Davidson and Anna Chaudhri. Woodbridge: D. S. Brewer, pp. 99-122.

de la Rochère, Martine Hennard Dutheil. 2013. Reading, Translating, Rewriting: Angela Carter's Translational Poetics. Detroit: Wayne State UP.

de la Rochère, Martine Hennard Dutheil, and Géraldine Viret. 2011. "Sleeping Beauty" in Chelmno: Jane Yolen's Briar Rose or Breaking the Spell of Silence. Etudes de Lettres 289: 399-420.

Gaiman, Neil. 2005. Smoke and Mirrors: Short Fictions and Illusions. London: Headline Review.

Harries, Elizabeth Wanning. 2005. The Violence of the Lambs. Marvels E Tales: Journal of Fairy-Tale Studies 19: 54-66.

Harries, Elizabeth Wanning. 2011. Old Men and Comatose Virgins: Nobel Prize Winners Rewrite "Sleeping Beauty". Etudes de Lettres 289: 359-78. [CrossRef]

Joosen, Vanessa. 2007. Disenchanting the Fairy Tale: Retellings of "Snow White" between Magic and Realism. Marvels \& Tales: Journal of Fairy-Tale Studies 21: 228-39.

Jorgensen, Jeana. 2019. Gender, Sexuality and the Fairy Tale in Contemporary American Literature. In The Fairy Tale World. Edited by Andrew Teverson. London and New York: Routledge, pp. 260-72. [CrossRef]

Landwehr, Margarete J. 2009. The Fairy Tale as Allegory for the Holocaust: Representing the Unrepresentable in Yolen's Briar Rose and Murphy's Hansel and Gretel. In Fairy Tales Reimagined: Essays on New Retellings. Edited by Susan Redington Bobby. Jefferson: McFarland, pp. 153-67.

Marshall, Elizabeth. 2009. Girlhood, Sexual Violence, and Agency in Francesca Lia Block's “Wolf". Children's Literature in Education 40: 217-34. [CrossRef]

Martin, Ann. 2010. Generational Collaborations in Emma Donoghue's Kissing the Witch: Old Tales in New Skins. Children's Literature Association Quarterly 35: 4-25. [CrossRef]

Martínez-Alfaro, María Jesús. 2020. The Broken Voice of History: Fairy Tales, Anti-Tales, and Holocaust Representation. In Contemporary Fairy-Tale Magic: Subverting Gender and Genre. Edited by Lydia Brugué and Auba Llompart. Leiden and Boston: Brill, pp. 201-10.

McAra, Catriona, and David Calvin. 2011. Anti-Tales: The Uses of Disenchantment. Newcastle upon Tyne: Cambridge Scholars Publishing.

Murphy, Louise. 2003. The True Story of Hansel and Gretel: A Novel of War and Survival. London: Penguin.

Rodríguez, Carolina Fernández. 2002. The Deconstruction of the Male-Rescuer Archetype in Contemporary Feminist Revisions of “The Sleeping Beauty". Marvels \& Tales: Journal of Fairy-Tale Studies 16: 51-70.

Russell, David L. 2002. Young Adult Fairy Tales for the New Age: Francesca Lia Block's The Rose and the Beast. Children's Literature in Education 33: 107-15. [CrossRef]

Solnit, Rebecca. 2019. Cinderella Liberator. London: Vintage.

Tatar, Maria, ed. 1999. The Classic Fairy Tales. London and New York: Norton \& Company.

Tiffin, Jessica. 2011. Blood on the Snow: Inverting "Snow White" in the Vampire Tales of Neil Gaiman and Tanith Lee. In Anti-Tales: The Uses of Disenchantment. Edited by Catriona McAra and David Calvin. Newcastle upon Tyne: Cambridge Scholars Publishing, pp. 220-30.

Warner, Marina. 1995. From the Beast to the Blonde: On Fairy Tales and Their Tellers. London: Vintage.

Warner, Marina. 2014. Once Upon A Time: A Short History of Fairy Tale. Oxford: OUP.

Yolen, Jane. 1992. Briar Rose. New York: Tor.

Zipes, Jack. 2001. The Great Fairy Tale Tradition: From Straparola and Basile to the Brothers Grimm. London and New York: Norton Critical Edition. 